\title{
Municipal Waste Management in Towns of Switzerland: a Foreign Ecologist's View
}

\author{
Roman Mamadzhanov ${ }^{1}$, Yulia Zakirova ${ }^{1}$, and Mykhadi Umarov ${ }^{2}$ \\ ${ }^{1}$ Peoples' Friendship University of Russia (RUDN University), Faculty of Ecology, 6 Miklukho- \\ Maklaya St, Moscow, 117198, Russian Federation \\ ${ }^{2}$ Complex Institute Named After Kh.I. Ibragimov of the Russian Academy of Sciences, \\ Staropromyslovskoe schosse, 21a, Grozny, the Chechen Republic
}

\begin{abstract}
The article presents the results of the research carried out by the foreign ecologists, particularly the study of the system of municipal waste management in the municipality of Maienfeld, Switzerland. The total amount of municipal waste has been calculated. The systems of municipal waste collection, sorting, transportation and recycling have been studied. Besides, four possible scenarios of waste recycling in Maienfeld have been developed. Moreover, the environmental assessment of the waste recycling system by GHG/SLCP emissions has been conducted, and the impact of recycling on the climate has been determined. Finally, taking into account the results of the research, the best scenario of recycling has been proposed.
\end{abstract}

\section{Introduction}

Currently, Switzerland is one of the countries in Western Europe with the highest per capita annual municipal waste generation $[1,2]$. On average, in Switzerland one person produces more than $714 \mathrm{~kg}$ of waste per year, in Germany - $638 \mathrm{~kg}$, in Austria - $610 \mathrm{~kg}$, Sweden $471 \mathrm{~kg}[1,2]$.

Nevertheless, in spite of economic and population growth from 2001 to 2010 the total amount of municipal waste in Switzerland increased only by $16 \%$, from 4,79 million tons in 2001 to 5,56 million tons in 2010 [3]. It is a good example of the stability of the municipal waste collection and recycling system over time.

According to the Federal Office for the Environment (FOEN), municipal waste covers household waste and generated by businesses waste similar in composition to household waste.

Marton Herczeg from Copenhagen Resource Institute notes that Switzerland has a long tradition in diverting waste from landfill to waste recycling and incinerating plants [3].

The above can be confirmed by the fact that the average percentage of recycled waste in 2001-2010 was approximately 50\%, recycled secondary materials (glass, metal, plastic, paper and cardboard) - more than $30 \%$, recycled organic waste - more than $15 \%$ (Fig. 1) [4]. For comparison, in 2011 the total percentage of recycled waste in Germany was $45 \%$, in Belgium - 36\%, in Denmark - 31\%. [4].

Before recycling rubbish should be separated and collected in containers. 
According to the Federal Office for the Environment (FOEN), there are eight types of waste which should be collected (Table 1) [5].

Table 1. Types of collected waste in Switzerland

\begin{tabular}{|c|c|c|c|}
\hline Type of Waste & $\begin{array}{c}\text { Recycling } \\
\text { Management }\end{array}$ & Profit & Collection site \\
\hline Paper and cardboard & Village/City & 10-50 CHF/1 ton & Public collection \\
\hline Glasspack & VetroSwiss & 2-6 Rappen/1 pack & Public collection \\
\hline WEEE $^{1}$ & SWICO $^{2} /$ S.E.N.S. ${ }^{3}$ & Depending on the type & Points of purchase \\
\hline Fluorescent lamps & SLRS $^{4} /$ S.E.N.S. & Depending on the type & Points of purchase \\
\hline PET bottles & $\mathrm{PRS}^{5}$ & 1,8 Rappen/Bottle & $\begin{array}{l}\text { Public collection/ } \\
\text { points of purchase }\end{array}$ \\
\hline Tin cans & FERRO recycling & 1 Rappen/Can & Public collection \\
\hline Aluminum cans & IGORA $^{6}$ & 2 Rappen/Can & $\begin{array}{l}\text { Public collection/ } \\
\text { points of purchase }\end{array}$ \\
\hline Batteries & INOBAT $^{7}$ & $3,20 \mathrm{CHF} / 1 \mathrm{~kg}$ & $\begin{array}{l}\text { Public collection/ } \\
\text { points of purchase }\end{array}$ \\
\hline \multicolumn{4}{|c|}{$\begin{array}{l}{ }^{1} \text { Waste electrical and electronic equipment } \\
{ }^{2} \text { Recycling of waste electrical and electronic e } \\
{ }^{3} \text { Recycling of household appliances } \\
{ }^{4} \text { Light Recycling Foundation in Switzerland } \\
\text { PET recycling in Switzerland } \\
{ }^{6} \text { Aluminum recycling company } \\
{ }^{7} \text { Batteries recycling company }\end{array}$} \\
\hline
\end{tabular}

It is apparent from Table 1 that biodegradable (organic) waste is not included in this system. Besides, end-of-life vehicles should also be recycled. Since 2006, the average cost of recycling a car is more than $30 \mathrm{CHF}$.

It is important that each year FOEN spends more than 7,2 million CHF on waste recycling management in Switzerland [6].

According to the FOEN report, the total amount of municipal waste in Switzerland is rapidly increasing [6]. For example, annually there are more than 840 million items of waste made of plastic, metal, cardboard, paper or cigarettes in Swiss streets or on highways. On average, every year there are more than 100 items of rubbish per capita.

Despite the high rates of municipal waste recycling, in towns with a population of less than five thousand people and a rapid increase in the total amount of waste, municipal waste is collected only once a week. Actually, refuse is collected in large rubbish bags accumulating in the streets before transportation in a few days. This can lead to accidental spread of insects, rodents or pathogenic compounds in the streets.

The aim of our research is to reveal advantages and disadvantages of municipal waste management in towns of Switzerland and consider applying the best ideas in Russia.

The main objectives are:

- to study the system of collection and segregation of municipal waste,

- to study the system of transportation of municipal waste and to develop proposals for its modernization;

- $\quad$ to describe the system of recycling of municipal waste;

- to do calculations related to the environmental assessment of the waste recycling system by GHG/SLCP (greenhouse gas / short-lived climate pollutant) emissions;

to determine the impact of GHG emissions from the waste recycling system on the climate and propose the best recycling scenario for Maienfeld. 


\section{Methods}

To study the system of collection and separation of municipal waste the open data set and our research data were used [7].

For studied the municipal waste transportation and recycling systems we used the knowledge and experience of employees of the A\&M AG recycling center in Landquart Switzerland.

The study of the system of transportation of municipal waste was based on knowledge and experience of employees of the A\&M AG recycling center in Landquart, Switzerland.

For the environmental assessment of the system of waste recycling and the impact of GHG emissions $\left(\mathrm{CO}_{2}, \mathrm{CH}_{4}, \mathrm{BC}\right.$ and $\left.\mathrm{N}_{2} \mathrm{O}\right)$ on the climate, we used the Emission Quantification Tool (EQT) for estimation of GHGs / SLCPs from solid waste sector developed by the Institute for Global Environmental Strategies (IGES).

We compared BAU (business as unusual) practice of waste recycling with four possible scenarios (scenario 1, 2, 3, 4). The key data set for this research is presented in Table 2. [8].

Table 2. The key data on recycling of municipal waste in Maienfeld.

\begin{tabular}{|l|c|c|c|c|c|}
\hline \multirow{2}{*}{ Parameter } & \multicolumn{5}{|c|}{ Tons/day } \\
\cline { 2 - 6 } & BAU & Scenario 1 & Scenario 2 & Scenario 3 & Scenario 4 \\
\hline \multicolumn{7}{|c|}{ Collected/Uncollected } \\
\hline $\begin{array}{l}\text { Total amount of generated } \\
\text { waste }\end{array}$ & 5,50 & 5,51 & 5,51 & 5,51 & 5,51 \\
\hline $\begin{array}{l}\text { Total amount of waste } \\
\text { collected and treated by } \\
\text { the municipality }\end{array}$ & 3,05 & 3,38 & 3,47 & 4,31 & 4,56 \\
\hline $\begin{array}{l}\text { Total amount of waste } \\
\text { collected and treated by } \\
\text { commercial companies }\end{array}$ & 2,01 & 1,73 & 1,47 & 1,02 & 0,86 \\
\hline $\begin{array}{l}\text { Total amount of } \\
\text { uncollected waste }\end{array}$ & 0,44 & 0,4 & 0,57 & 0,18 & 0,09 \\
\hline & 1,00 & 2,00 & 2,00 & 3,00 & 4,00 \\
\hline Recycling & 1,00 & 1,00 & 1,00 & 1,00 & 1,00 \\
\hline Incineration & 1,00 & 0,00 & 0,00 & 0,00 & 0,00 \\
\hline Landfill disposal
\end{tabular}

It is important that BAU was calculated using the IGES computer model [8]. Scenarios were as close as possible to real-life conditions of waste management in Maienfeld.

As can be seen from Table 2, all scenarios have remained unchanged taking into account the data on the total amount of waste in 2019. Meanwhile, other parameters have significantly changed.

The GHG emissions from waste recycling were measured per one ton of generated waste $(\mathrm{kg} / \mathrm{ton})$, the impact on the climate $-\mathrm{kg}$ of $\mathrm{CO}_{2}$-eq/ton.

It should be mentioned that the same technological treatment method (including extraction of nonferrous and ferrous metals, glasspacks, treatment of paper and cardboard) is used in each of the above scenarios.

\section{Results}

The object of our research is Maienfeld, a municipality in the Landquart Region in the eastern part of Switzerland, in the canton of Graubünden. The total area of Maienfeld is $32,33 \mathrm{~km}^{2}$, the population is 2587 people [9]. 
Maienfeld is bordered on the west by Bad Ragaz, Canton of St. Gallen and on the west and north by the community of Fläsch, Canton Graubünden. To the north it is bordered by Balzers, Triesen, Schaan, the country of Liechtenstein, Nenzing and Vorarlberg, Austria. To the east is the community of Seewis im Prättigau, Canton Graubünden. To the southwest Jenins und Malans, Canton Graubünden. In the south it is bordered by Igis and Zizers, Canton Graubünden, as well as in the southwest the community of Mastrils, Canton Graubünden.

From the environmental point of view, the agrolandscape occupies $44,3 \%$ of the area, forests $-31,9 \%$, social infrastructure facilities $-5,4 \%$ [9]. In addition, the Rhine river flows through Maienfeld. Consequently, the environmental issues (particularly municipal waste management) are among the major ones for Maienfeld.

The total amount of municipal waste in Maienfeld averages 1841,9 tons per year.

All categories of municipal waste should be separated (Table 1). Nevertheless, people can buy special blue bags (for 14 CHF per 10 bags) to collect all types of municipal waste without separation. It should be noted that the price of a kitchen rubbish bag (only for organic waste) is $2 \mathrm{CHF}$ per 20 bags. Thus, Maienfeld has a special tax on unsorted waste.

All containers for municipal waste are divided into:

- containers for unsorted (sorted) municipal waste;

- containers for dog excrement;

- containers for glass, cans, paper and PET;

- containers for wooden items, street dust.

As we can see, the bulk of municipal metal waste, WEEE, including batteries and fluorescent lamps is excluded from this waste separation system. These categories of waste should be separated in Landquart city in the A\&M AG recycling center situated $5,5 \mathrm{~km}$ away from Maienfeld. People need to go there on their own. Due to that, the transportation cost of recycling of batteries and fluorescent lamps is higher.

The system of municipal waste transportation in Maienfeld includes:

- transportation of waste from waste containers to the recycling center (A\&M AG recycling center);

- waste treatment including reuse of secondary materials, incineration of unrecyclable materials at incineration plants;

- landfill disposal.

It is important that collected waste is transported to the recycling center only once a week in summer, and once a fortnight in winter. All rubbish collected into bags and special containers from households is left in the streets by residents to be transported in 3-5 days. According to our study, more than $40 \%$ of these bags are disturbed by rodents, cats and dogs. They look for organic remains to feed on them. This can lead to accidental spread of pathogenic bacteria in the environment.

The strategy for waste management in Maienfeld aims at reducing the total amount of unrecyclable waste after treatment. The hierarchy of waste management in Maienfeld is the same as all over Switzerland and consists of reduction, reuse, recycling, incineration and landfill disposal technologies.

The main idea of waste recycling system in Maienfeld is to reduce the total amount of waste and to make the most of reuse of secondary materials. Besides, «recycling» takes third place after collection and separation. In addition, incineration and landfill disposal methods are used only to reduce unrecyclable materials. Overall, this approach prevents the ingress of toxic compounds (which are dioxins, chlorine and benzene) into the atmosphere and the topsoil.

The results of environmental assessment of the waste recycling system by GHG/SLCP emissions are shown in Fig. 1. 


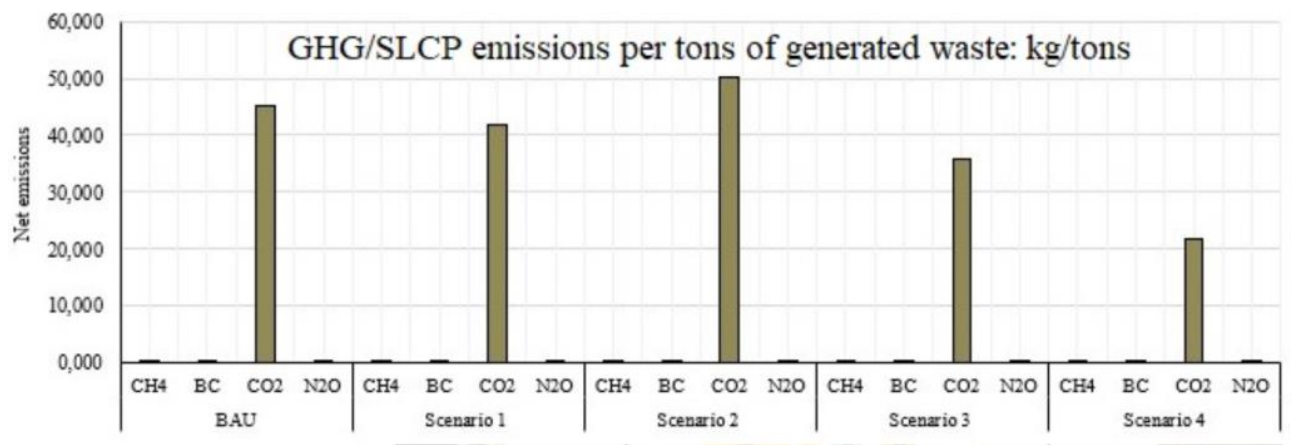

Fig. 1. GHG emissions from waste recycling.

Fig. 1 shows that the highest GHG/SLCP emission level is in Scenario $2(50,98$ $\mathrm{kg} /$ ton $)$ and it is higher than in BAU $(45,82 \mathrm{~kg} / \mathrm{ton})$, while the GHG emission in Scenario 4 is lower $(22,38 \mathrm{~kg} /$ ton $)$. Scenarios 1 and 3 also show the higher GHG/SLCP emission level with 42,49 and $36,46 \mathrm{~kg} /$ ton correspondingly, but it is lower than in BAU.

As we have noted, upon recycling toxic compounds (which are GHG/SLCP emissions) enter the environment. One of the main GHGs is $\mathrm{CO}_{2}(<20,00 \mathrm{~kg} / \mathrm{ton}$ of waste in each scenario). Meanwhile, the total amount of $\mathrm{N}_{2} \mathrm{O}$ and $\mathrm{CH}_{4}$ is lower $(>1,00 \mathrm{~kg} / \mathrm{ton}$ of waste in each scenario). This can be explained by the significant amount of $\mathrm{CO}_{2}$-eq due to fuel (gasoline or diesel) use for transportation of waste to the recycling facility and recycling itself.

The impact of waste recycling on the climate taking into account $\mathrm{CO}_{2}$-eq/ton shows, that the minimal impact of GHGs, particularly $\mathrm{CO}_{2}$-eq emissions upon recycling is in Scenario $4\left(21,70 \mathrm{~kg}\right.$ of $\mathrm{CO}_{2}$-eq/ton), which is less than in BAU. The maximum impact on the climate is in Scenario $2\left(50,09 \mathrm{~kg}\right.$ of $\mathrm{CO}_{2}$-eq/ton).

It could depend on the decrease in the total amount of waste collected and treated by the municipality (3,47 tons/day) and the increase in the total amount of uncollected waste $(0,57$ tons/day) in Scenario 2. In Scenario 4 the total amount of waste collected and treated by the municipality is 4,56 tons/day and the total amount of uncollected waste is 0,09 tons/day.

It should be noted that Scenario 4 has got one of the highest recycling rates (more than $70,00 \%$ of the total amount of waste/day, or 4,00 tons/day (Table 2). Meanwhile, the recycling rate in Scenario 2 is only $36,30 \%$ of the total amount of waste/day, or 2,00 tons/day (Table 2).

\section{Conclusion}

In conclusion, we should say that the system of collection and separation of municipal waste in Maienfeld is modern and eco-friendly. It is confirmed by the high rates of collection of municipal waste (more than $50,00 \%$ in each scenario), and by waste sorting into four containers. In view of all that has been mentioned so far, it would be interesting to consider the possibility of implementation of the waste sorting system in towns of Russia.

The transportation system needs to be improved. Collected household waste is transported to the recycling center only once a week in summer, and once a fortnight in winter. All the waste collected into bags and special containers (Fig. 1) from households is left in the streets by residents to be transported in 3-5 days. According to our study, more than $40 \%$ of these bags are disturbed by rodents, cats and dogs. They look for organic remains to feed on them. This can lead to accidental spread of pathogenic bacteria in the environment. 
The results of our study of the waste recycling system in Maienfeld allowed us to determine four scenarios of recycling. We consider Scenario 4 as the best recycling scenario for Maienfeld with the lowest level of GHG/SLCP emissions $\left(21,70 \mathrm{~kg}\right.$ of $\mathrm{CO}_{2}$ eq/ton of waste) and the minimal impact on the climate taking into account GHG emissions $\left(21,70 \mathrm{~kg}\right.$ of $\mathrm{CO}_{2}$-eq/ton). As a result, technological options used in this Scenario seem to be the most appropriate choice for Maienfeld.

Our recommendations are the following:

- to compare systems of waste management in Maienfeld and in other towns of Switzerland:

- accordingly, to identify the best system of waste management for towns of Switzerland;

- besides, the environmental assessment of waste incineration and landfill dumping technologies should be carried out;

- cost-effectiveness of waste management including collection, separation and recycling should be studied;

- based on this experience to consider the possibility of implementation of the best ideas of waste management in towns of Russia.

\section{References}

1. Swiss are champions in waste management URL.: https://www.swissinfo.ch

2. W. Joos, V. Carabias, H. Winistoerfer, A. Stuecheli, Waste management, 19, 417-425 (1999)

3. Municipal waste management in Switzerland URL.: https://www.bafu.admin.ch/bafu/en/home

4. Separate waste system URL.: http://www.separate-wastesystems.eu

5. Ordinance on the Avoidance and the Disposal of Waste URL.: https://www.admin.ch/

6. Zero littering URL.: https://www.bafu.admin.ch

7. A\&M AG Recycling center URL.: https://recycling-center.ch

8. Emission Quantification Tool (EQT) for estimation of GHGs/SLCPs from solid waste sector URL.: https://www.iges.or.jp

9. Stadt Maienfeld URL.: http://www.maienfeld.ch/de/ 